\title{
PERAN PERCEIVED USEFULNESS DALAM MEMEDIASI PENGARUH KEPERCAYAAN TERHADAP MINAT BELI MASYARAKAT DI KOTA DENPASAR
}

\author{
Putu Rico Pradana ${ }^{1}$ \\ Gede Bayu Rahanatha ${ }^{2}$ \\ ${ }^{1,2}$ Fakultas Ekonomi dan Bisnis Universitas Udayana, Bali, Indonesia \\ email: pradanarico@yahoo.com
}

\begin{abstract}
ABSTRAK
Tujuan penelitian ini adalah untuk menjelaskan dan memperoleh bukti empiris mengenai pengaruh kepercayaan terhadap perceived usefulness, pengaruh kepercayaan dan perceived usefulness terhadap minat beli. Populasi dalam penelitian ini adalah konsumen di Kota Denpasar yang memiliki minat pembelian produk fashion pada toko onlineZalora. Jumlah sampel yang digunakan dalam penelitian ini adalah sebanyak 110 responden. Teknik analisis data yang digunakan dalam penelitian ini adalah analisis jalur (Path Analysis). Hasil penelitian menunjukkan bahwa kepercayaan berpengaruh positif dan signfikan terhadap perceived usefulness, kepercayaan berpengaruh positif dan signfikan terhadap minat beli konsumen, perceived usefulness berpengaruh positif dan signifikan terhadap minat beli konsumen, dan perceived usefulness secara positif dan signifikan memediasi pengaruh kepercayaan terhadap minat beli konsumen. Hal ini memiliki maknabahwa konsumen yang sudah memiliki kepercayaan pada produk fashion toko online Zalora, kemudian didukung dengan adanya persepsi manfaat yang baik bagi konsumen, maka dapat meningkatnya minat beli konsumen pada situs online Zalora tersebut.

Kata Kunci: perceived usefulness, kepercayaan, minat beli, toko online, fashion
\end{abstract}

\begin{abstract}
The purpose of this study is to explain and obtain empirical evidence about the effect of trust on perceived usefulness, the effect of trust and perceived usefulness on buying interest. The population in this study is consumers in the city of Denpasar who have an interest in buying fashion products at the online store Zalora. The number of samples used in this study were 110 respondents. The data analysis technique used in this research is Path Analysis. The results showed that trust has a positive and significant effect on perceived usefulness, trust has a positive and significant effect on consumer buying interest, perceived usefulness has a positive and significant effect on consumer buying interest, and perceived usefulness positively and significantly mediates the effect of trust in consumer buying interest. This has the meaning that consumers who already have confidence in Zalora's online store fashion products, then supported by the perception of good benefits for consumers, can increase consumer buying interest in the online site Zalora.
\end{abstract}

Keywords: perceived usefulness, trust, buying interest, online shop, fashion 


\section{PENDAHULUAN}

Seiring dengan perkembangan zaman yang makin canggih, penggunaan teknologi seperti internet sudah tidak asing lagi. Perkembangan teknologi internet yang semakin canggih memberikan manfaat bagi banyak pihak, termasuk para pelaku bisnis di Indonesia. Bisnis online berkembang pesat di tanah air yang ditandai dengan semakin banyaknya pelaku bisnis menggunakan internet sebagai media pemasaran mereka, seperti untuk berpromosi, berinteraksi dan berhubungan dengan pelanggan (Juniwati, 2015).

Kegiatan transaksi jual beli dengan menggunakan internet sudah sangat marak dikalangan masyarakat atas, menengah maupun masyarakat biasa. Konsumen sudah tidak perlu lagi untuk keluar rumah jika ingin belanja sesuatu, hanya dengan bermodalkan smartphone, laptop, ataupun notebook yang menggunakan akses internet dan berbagai macam aplikasi sosial media lainnya (Setiawati, 2015). Saat ini gaya hidup masyarakat di Indonesia lebih banyak yang memanfaatkan internet untuk mengakses media sosial. Hal ini diperkuat dengan data hasil survey Asosiasi Penyelenggara Jasa Internet Indonesia (APJII) pada Tahun 2017 mengenai pemanfaatan internet bidang gaya hidup seperti yang tercantum dalam Gambar 1 sebagai berikut :

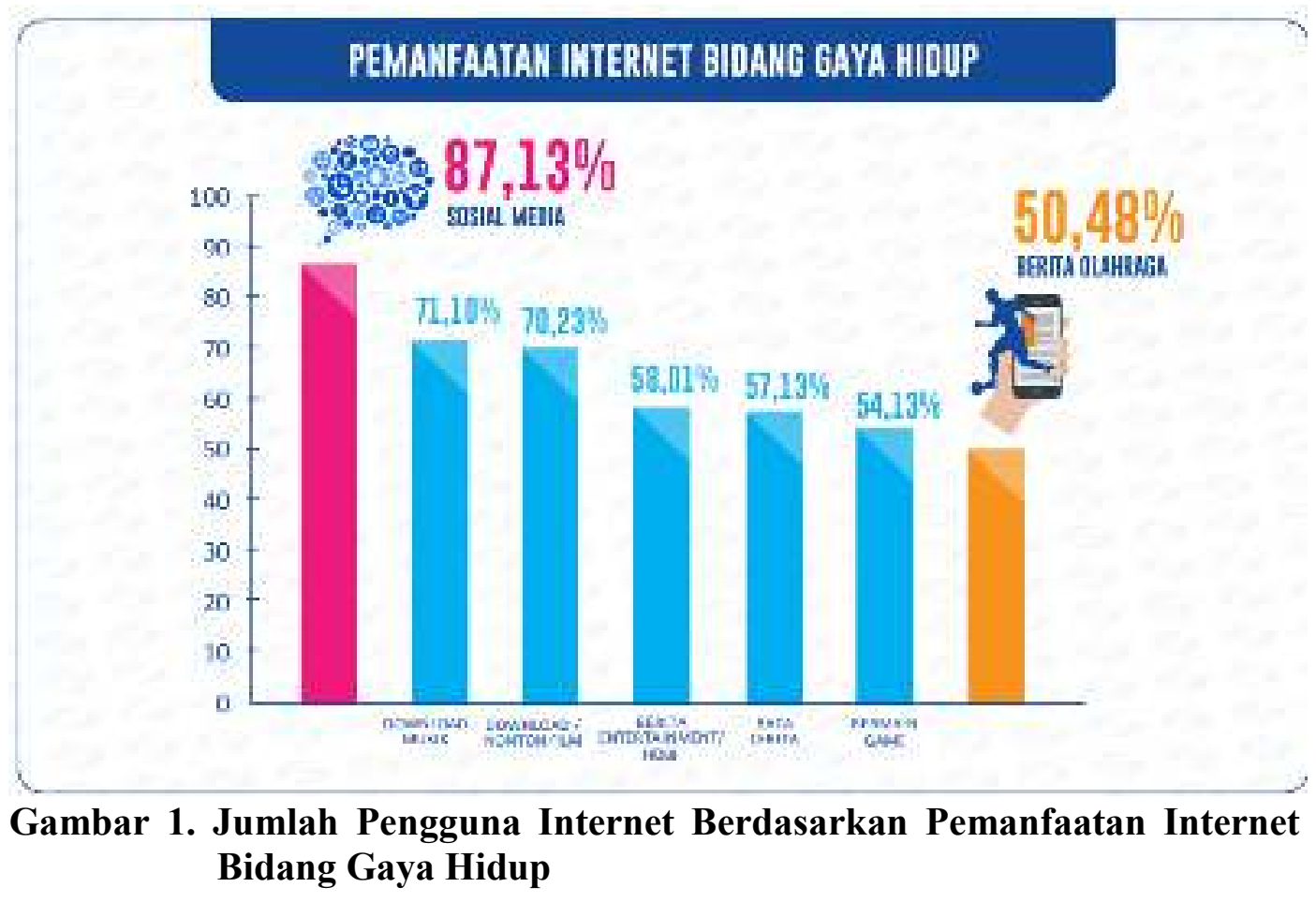

Sumber : Asosiasi Penyelenggara Jasa Internet Indonesia (APJII), 2017

Gambar 1. menunjukkan jumlah pengguna internet di Indonesia mayoritas memiliki gaya hidup menggunakan internet untuk mengakses media sosial dengan jumlah sebanyak 87,13 persen. Fenomena tersebut merupakan peluang besar bagi para produsen yang menawarkan kemudahan kepada konsumen untuk menjual 
produknya menggunakan media sosial. Manfaat media sosial yang lain bagi konsumen adalah bahwa mereka dapat berbelanja tanpa meninggalkan rumah atau membandingkan harga suatu produk dari suatu toko ke toko lainnya hanya dengan menggunakan media sosial (Rachmawati, Wahyudi, \& P, 2016).

Fenomena gaya hidup masyarakat yang aktif menggunakan atau mengakses internet ini juga terjadi di provinsi Bali. Tabel 1 berikut merupakan data yang diperoleh dari Badan Pusat Statistik Provinsi Bali mengenai persentase penduduk yang mengakses internet menurut Kabupaten/Kota Pada Tahun 2017.

Tabel 1.

Persentase Penduduk yang Mengakses Internet Menurut Kabupaten/Kota di Provinsi Bali Pada Tahun 2017

\begin{tabular}{lcc}
\hline & Kabupaten/Kota & Mengakses Internet \\
\hline Denpasar & 59.78 \\
Badung & 54.62 \\
Gianyar & 39.76 \\
Tabanan & 32.71 \\
Jemberana & 28.27 \\
Klungkung & 26.82 \\
Bangli & 25.12 \\
Buleleng & 24.75 \\
Karangasem & 22.73 \\
\hline
\end{tabular}

Sumber: Badan Pusat Statistik Provinsi Bali, 2017

Tabel 1. menunjukkan bahwa persentase penduduk yang lebih banyak mengakses internet yakni terdapat pada Kota Denpasar yaitu mencapai 59,78 persen penduduk. Kemudian disusul oleh Kabupaten Badung dengan persentase penduduk mencapai 54,62 persen yang aktif mengakses internet, Gianyar mencapai 39,76 persen, Tabanan mencapai 32,71 persen dan penduduk yang paling jarang mengakses internet terdapat pada Kabupaten Karangasem dengan jumlah sebanyak 22,73 persen. Data tersebut memberi informasi bahwa pengguna internet di Bali masih dominan terpusat di Denpasar. Hal ini disebabkan karena Kota Denpasar merupakan salah satu Kota yang memiliki kepadatan penduduk tertinggi di Bali dan di dukung dengan daya beli yang cukup tinggi, dimana mayoritas masyarakatnya merupakan masyarakat modern yang saat ini kebanyakan memenuhi kebutuhan hidupnya dengan menggunakan media online.

Maraknya penggunaan media online dalam penjualan dan promosi produk atau jasa, sangat mempengaruhi opini dan minat beli konsumen. Pemasaran yang dilakukan melalui internet ataupun media online dapat meningkatkan penjualan dan promosi produk atau jasa yang lebih efisien dan efektif. Media sosial cenderung mengembangkan strategi pemasaran (marketing) dalam suatu perusahaan melalui mekanisme kepercayaan dan mempengaruhi konsumen untuk membeli produk secara online. Melalui komunitas online dan SNS (Social Networking Sites), konsumen akan lebih mudah untuk berbagi informasi. Konsumen memiliki akses ke berbagai sumber informasi yang berbeda-beda yang dibagi atau dipublikasikan oleh konsumen lainnya (Liang \& Turban 2011).

Cara berbelanja yang dilakukan konsumen via internet ini dapat disebut dengan beberapa nama yaitu online shopping, online buying behavior, dan 
internet shopping (Li \& Zhang, 2002). Semua nama ini mengacu pada proses jual beli barang dan jasa via internet menggunakan media sosial atau pun website. Konsumen saat ini menggunakan teknologi dalam kehidupan sehari-hari terutama media sosial sebagai alat yang efektif untuk proses online shopping. Berinteraksi dengan konsumen di media sosial akan meningkatkan konsumen yang potensial dan kemungkinan tinggi untuk merubah konsumen yang potensial menjadi konsumen tetap. Selain untuk mendapatkan konsumen tetap, media sosial juga menjadi suatu wadah bagi konsumen untuk mempromosikan dan berbagi pengalaman mereka kepada sesama pengguna media sosial mengenai pengalaman positif atau negatifnya dalam menggunakan produk atau jasa yang dibeli.

Fenomena tersebut menyebabkan banyak toko online bermunculan seperti Lazada, Tokopedia, Blibli, Shopee, JD ID, Bhineka, Elevenia, Zalora, Mataharimall dan masih banyak lagi toko online lainnya. Para $e$ commerce tersebut berlomba menjaring pengguna internet berkunjung ke tokonya untuk berbelanja, baik secara langsung dari aplikasi maupun melalui media online.

Jumlah toko online yang semakin banyak seiring meningkatnya konsumen pengguna media sosial yang semakin banyak menyebabkan toko online harus mampu mengidentifikasi apa yang menjadi produk utama yang diinginkan seorang konsumen dalam transaksi online tersebut, agar dapat mempertahankan posisinya pada peringkat utama. Berdasarkan hasil riset Nielsen Indonesia, produk terlaris yang dibeli konsumen pada hari belanja online nasional adalah produk fashion. Hal ini diperkuat dengan data yang terdapat dalam Gambar 2.

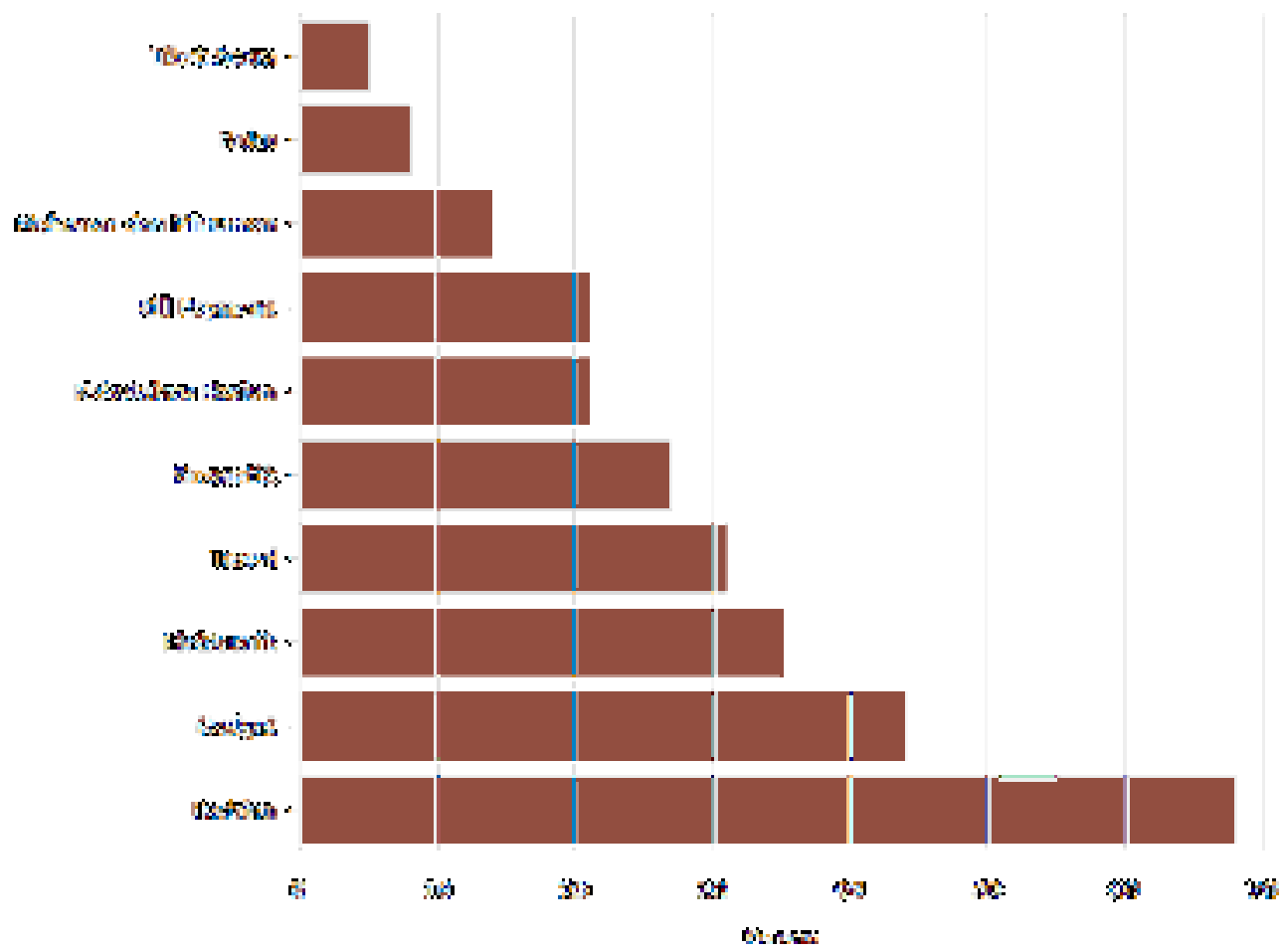

Gambar 2. Produk Terlaris Saat Hari Belanja Online Nasional Sumber : Databoks.co.id, 2018 
Gambar 2. menunjukkan bahwa produk fashion paling banyak dibeli para konsumen digital pada Hari Belanja Online Nasional (Harbolnas) 12-14 Desember 2016. Hasil riset dari Nielsen Indonesia mencatat penjualan produk ini mencapai 68 persen dari total perdagangan. Produk mode yang banyak dibeli seperti pakaian, tas, sepatu, perhiasan, hingga aksesoris. Tingginya persentase pada kategori fashion dan aksesoris di Indonesia menandakan bahwa banyaknya peminat produk fashion yang membuat semakin banyak juga bentuk penawaran dari para pelaku bisnis pada komoditi fashion (Mubarak dan Sanawiri, 2018).

Penelitian ini dilakukan pada konsumen yang memiliki minat beli online produk fashion melalui Zalora. Alasan menggunakan Zalora sebagai objek penelitian, karena Zalora merupakan salah satu online fashion di Indonesia yang menjual fashion dengan merek-merek terkenal dan menduduki posisi pertama TOP BRAND dalam top brand award tahun 2018 namun memiliki jumlah pengunjung yang lebih sedikit dibandingkan dengan online shop fashion seperti Lazada, Shopee dan lainnya seperti yang terangkum dalam Gambar 3.

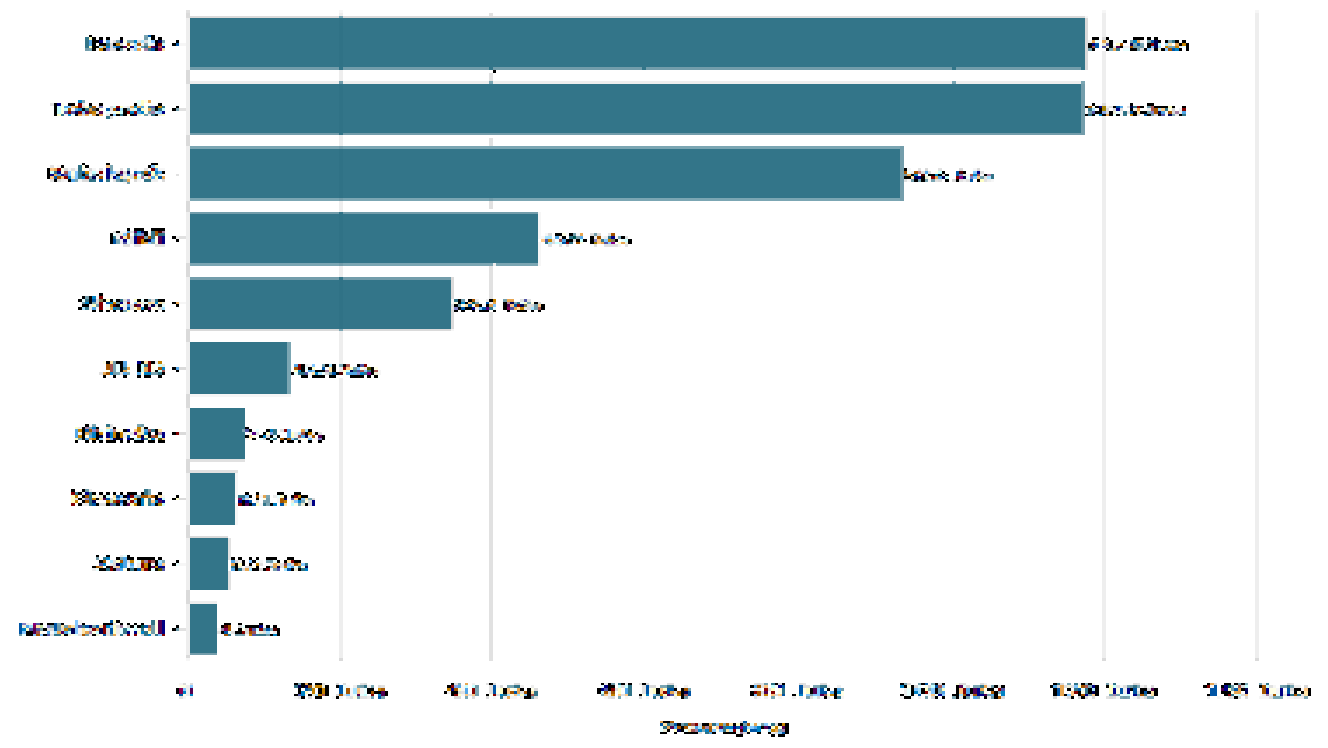

Gambar 3. E-commerce dengan Pengunjung Terbanyak TW I 2018

Sumber: Databoks.co.id, 2018

Gambar 3. merupakan hasil studi terbaru Peta E-commerce iPrice pada kuartal pertama 2018 yang menunjukkan bahwa Zalora belum mampu mencapai posisi pertama sebagai marketplace dengan pengunjung terbanyak. Walaupun Zalora memperoleh Top Brand Award pada kategori online shop fashion pada tahun 2018 mengalahkan Lazada, namun jumlah pengunjung Zalora hanya mencapai 5,2 juta pengunjung lebih kecil dibandingkan mengunjung Lazada yang mencapai 117,6 juta pengunjung.

Keadaan ini tentu harus dapat dibenahi oleh Zalora agar dapat mencapai peringkat pertama sebagai marketplace dengan pengunjung terbanyak pada kategori online shop fashion. Oleh karena itu pihak marketing Zalora harus dapat menarik minat konsumen untuk melakukan pembelian produk fashion pada situs online Zalora. Minat beli konsumen adalah sesuatu yang timbul setelah menerima 
rangsangan dari produk yang dilihatnya, dari sana timbul ketertarikan untuk mencoba produk tersebut sampai pada ahkirnya timbul keinginan untuk membeli agar dapat memilikinya (Jannah, 2017). Menurut penelitian Hajli (2013) minat beli konsumen dapat dipengaruhi oleh kepercayaan dan persepsi manfaat yang diterima konsumen dalam melakukan transaksi secara online. Dengan demikian, untuk menarik minat beli pengunjung, maka Zalora harus dapat memberikan manfaat bagi konsumen dan menumbuhkan keyakinan dalam benak konsumen saat berbelanja online. Apabila toko online mampu memberikan manfaat yang baik dan keyakinan dalam berbelanja online pada konsumen, maka dapat menumbulkan minat konsumen dalam berbelanja online terutama pada produk fashion (Smeait, 2016).

Media online memainkan peran yang signifikan dalam kehidupan konsumen. Pemasar mengiklankan produk dan jasa mereka melalui media online agar strategi marketing dapat berjalan dengan cepat. Hubungan konsumen melalui media online seperti komunitas, review, dan rekomendasi dapat membangun dan meningkatkan kepercayaan dalam e-commerce (Weisberg et al., 2011). Semakin banyak komentar, feedback, dan rating yang positif menghasilkan level kepercayaan yang tinggi. Hal ini menunjukkan bahwa dengan adanya interaksi sosial di antara konsumen dalam media sosial dapat membantu konsumen lainnya memperoleh informasi terkait produk ataupun jasa yang ditawarkan, sehingga dapat mempengaruhi kepercayaan konsumen.

Kepercayaan dalam transaksi dan jaringan online mempengaruhi perilaku pembeli online dan meningkatkan niat untuk membeli. Interaksi antara pengguna online dapat meningkatkan kepercayaan dan kepercayaan memiliki peran penting dalam mempengaruhi niat konsumen untuk membeli. Faktanya, semakin tinggi kepercayaan konsumen, semakin tinggi juga niat mereka untuk membeli. Oleh karena itu, kepercayaan sangat mempengaruhi keinginan konsumen untuk bertransaksi. Hasil penelitian Hajli (2013) menemukan bahwa kepercayaan berpengaruh positif dan signifikan pada niat beli konsumen. Hal serupa juga ditemukan oleh Nusarika dan Purnami (2015) yang memperoleh hasil bahwa semakin tinggi kepercayaan konsumen online akan menghasilkan niat beli konsumen yang lebih tinggi pula untuk berbelanja secara online. Berbeda dengan hasil penelitian yang dilakukan Smeait (2016) yang menemukan bahwa variabel kepercayaan atau keyakinan berpengaruh negatif terhadap minat beli produk fashion melalui online yang menandakan konsumen tidak yakin dengan melakukan pembelian secara langsung melalui online dengan tidak melihat produk yang akan di beli dengan harga yang sudah ditentukan oleh penjual.

Hasil penelitian Rachmawati dkk. (2016) menemukan hasil bahwa variabel kepercayaan memiliki pengaruh positif dan signifikan terhadap minat beli pada transaksi jual beli online melalui media sosial. Semakin tinggi kepercayaan konsumen terhadap penjual produk secara online, maka semakin tinggi minat untuk membeli produk melalui media sosial. Dapat diasumsikan bahwa ketika responden menggunakan media sosial pada dasarnya mempercayai penjual yang menawarkan produk barang maupun jasa di media sosial. Oleh karena itu, semakin sering responden mengunjungi media sosial yang didalamnya ada seorang penjual yang menwarkan produk barang atau jasanya, kemungkinan 
tinggi bahwa mereka mempercayai penjual yang menjual produknya di media sosial tersebut.

Kepercayaan merupakan faktor penting bagi konsumen untuk memutuskan akan melakukan transaksi secara online atau tidak. Faktor kepercayaan adalah perkiraan subyektif dimana konsumen percaya mereka dapat melakukan transaksi online secara konsisten sesuai dengan yang diharapkan. Hasil penelitian Hajli (2013) menemukan bahwa terdapat hubungan positif antara kepercayaan dengan perceived usefulness. Hal serupa juga ditemukan oleh penelitian Sugiantoro dan Isharijadi (2015) yang memperoleh hasil bahwa variabel trust berpengaruh positif dan signifikan pada perceived usefulness. Sehingga upaya tinggi harus dilakukan oleh penyelenggara online shop agar kepercayaan konsumen semakin tinggi, karena trust mempunyai pengaruh besar pada pemanfaatan konsumen untuk melakukan transaksi secara online atau tidak melakukannya.

Persepsi manfaat yang dirasakan terhadap suatu e-commerce dapat ditingkatkan ketika website e-commerce tersebut mampu memberikan manfaat atau memudahkan berlangsungnya suatu aktivitas belanja online dari penggunanya. Jika situs e-commerce dilengkapi dengan akses yang cepat, kemudahan pencarian produk, dan sesuai dengan kebutuhan pengguna maka hal tersebut dapat memunculkan sikap positif dari pengguna terhadap situs tersebut, sehingga dapat meningkatkan minat beli konsumen (Faradila dan Soesanto, 2016). Penelitian serupa oleh Lukas (2017) memperoleh hasil bahwa manfaat yang dirasakan konsumen (perceived usefulness) memiliki efek positif terhadap niat pembelian konsumen. Berbeda dengan hasil temuan Yudiarti (2017) dan Pratiwi (2018) yang menemukan bahwa perceived usefulness tidak berpengaruh signifikan terhadap minat membeli konsumen. Namun penelitian yang dilakukan oleh Basyar (2016), Nursiah (2017) dan Jannah (2017) memperoleh hasil bahwa persepsi manfaat (perceived usefulness) berpengaruh positif dan signifikan pada minat beli konsumen. Hal ini menunjukkan bahwa persepsi kemanfaatan yang tinggi cenderung akan mendukung perubahan yang terjadi di dalam keputusan pembelian konsumen.

Kepercayaan (trust) adalah suatu konsep abstrak dan pada umumnya pada penelitian psikologis terlihat sebagai kepercayaan interpersonal. Dalam pemasaran, kepercayaan dipelajari dari perspektif pemasaran relasional. Dalam penelitian saat ini, kepercayaan mengacu pada kepercayaan pembeli atau menjual dalam penggunaan media sosial. Percaya dengan keyakinan berarti pembeli percaya bahwa penyedia layanan memiliki setidaknya satu karakteristik bermanfaat bagi mereka. Dengan demikian, dapat dikatakan bahwa kepercayaan pembeli di media sosial akan mempengaruhi nilai dan tujuan mereka membeli (Purwanto, 2017).

Kepercayaan adalah sikap dan harapan suatu pihak bahwa hubungan yang terjalin dan hasil yang diperoleh akan bermanfaat bagi kepercayaan itu sendiri kepercayaan itu muncul dalam jangka waktu yang lama dan bukan hal yang instant tercipta dalam suatu hubungan. Dalam menjalin suatu hubungan baik di bidang jasa maupun manufaktur kepercayaan merupakan dasar dari hubungan jangka panjang karena jika sudah mendapatkan kepercayaan akan membuat keinginan untuk membeli barang atau jasa yang disediakan oleh perusahaan. 
Kepercayaan merupakan perantara atau kunci dalam membangun hubungan jangka panjang bagi pelanggan dimana pelanggan tersebut memiliki orientasi yang tinggi terhadap organisasi (Setiawan dan Ukudi, 2007:271).

Kepercayaan pembeli terhadap website online shop terletak pada popularitas website online shop tersebut. Semakin popularitas suatu website, maka pembeli lebih yakin dan percaya terhadap reliabilitas website tersebut. Selanjutnya, kepercayaan pembeli terhadap penjual online terkait dengan keandalan penjual online dalam menjamin keamanan bertransaksi dan meyakinkan transaksi akan diproses setelah pembayaran dilakukan oleh pembeli (Setiawati dkk., 2015).

Kepercayaan sangat penting di dalam hubungan pemasaran karena dengan adanya kepercayaan segala sesuatu dapat berjalan dengan baik dan kepercayaan itu sendiri membuat terjalinnya hubungan yang sangat erat terhadap pelanggan sehingga setelah adanya kepercayaan menimbulkan keinginan untuk membeli produk tersebut. Kepercayaan sangatlah penting dalam pembelian secara online maka dari itu perusahaan harus sangat berhati-hati agar kepercayaan pelanggan tidak cepat hilang begitu saja

Perceived usefulness (PU) adalah salah satu dasar dari gagasan Technology Acceptance Model (TAM). Definisi perceived usefulness dapat diartikan sebagai tingkatan sejauh mana seseorang mempercayai penggunaan sistem tertentu yang akan meningkatkan kinerja seseorang tersebut (Davis 1989, 26).

Konsep ini juga menggambarkan manfaat sistem bagi pemakainya yang berkaitan dengan productivity (produktivitas), job performance atau effectiveness (kinerja tugas atau efektivitas), importance to job (pentingnya bagi tugas), dan overall usefulness (kebermanfaatan secara keseluruhan). Lingkungan berbelanja yang di desain dengan baik akan memberikan konsumen suasana hati yang baik sehingga dapat meningkatakan kepuasan berbelanja dan kemungkinan untuk berbelanja secara spontan.

Dalam penelitian ini, hanya perceived usefulness dan niat seseorang untuk membeli (intention to buy) adalah faktor utama dalam mengembangkan model tersebut. Kualitas dari suatu website yang berhubungan dengan sistem, pelayanan, dan kualitas informasi memiliki dampak signifikan terhadap perceived usefulness, yang akan meningkatkan niat konsumen untuk membeli.

Dalam keadaan dimana konsumen memiliki interaksi sosial, member menjadi familiar antara satu sama lain dan menjadi salah satu sumber yang terpercaya. Ini dapat sangat mempengaruhi niat pengguna media sosial untuk membeli (Gefen 2002).

Kepercayaan merupakan faktor penting bagi konsumen untuk memutuskan akan melakukan transaksi secara online atau tidak. Faktor kepercayaan adalah perkiraan subyektif dimana konsumen percaya mereka dapat melakukan transaksi online secara konsisten sesuai dengan yang diharapkan. Hasil penelitian Hajli (2013) menemukan bahwa terdapat hubungan positif antara kepercayaan dengan perceived usefulness. Hal serupa ditemukan oleh penelitian Sugiantoro dan Isharijadi (2015) yang memperoleh hasil bahwa variabel kepercayaan berpengaruh positif dan signifikan pada perceived usefulness. Sehingga upaya tinggi harus dilakukan oleh penyelenggara online shop agar kepercayaan konsumen semakin tinggi, karena kepercayaan mempunyai pengaruh besar pada 
pemanfaatan konsumen untuk melakukan transaksi secara online atau tidak melakukannya.

Temuan penelitian Faradila dan Soesanto (2016) memperoleh hasil bahwa ada hubungan yang positif dan signifikan antara kepercayaan dan persepsi manfaat, dimana semakin tinggi tingkat kepercayaan konsumen maka akan semakin tinggi persepsi akan manfaat yang dirasakan konsumen tersebut. Hasil Penelitian Kusumawati (2015) juga memperoleh hasil yaitu persepsi manfaat berpengaruh positif terhadap kepercayaan. Purnami (2016) dalam penelitiannya menemukan bahwa persepsi manfaat berpengaruh signifikan pada kepercayaan. Apabila konsumen sudah merasa bahwa bertransaksi online mudah, bermanfaat dan menguntungkan, maka konsumen akan merasa semakin percaya dan puas terhadap layanan yang diberikan dan akan semakin loyal dengan layanan tersebut.

Berdasarkan hasil-hasil penelitian sebelumnya, maka dapat ditentukan hipotesis sebagai berikut:

$\mathrm{H}_{1}$ : Kepercayaan berpengaruh positif dan signifikan terhadap perceived usefulness

Kepercayaan dalam transaksi dan jaringan online mempengaruhi perilaku pembeli online dan meningkatkan niat untuk membeli. Interaksi antara pengguna online dalam SNS meningkatkan kepercayaan dan kepercayaan memiliki peran penting dalam mempengaruhi niat konsumen untuk membeli. Faktanya, semakin tinggi kepercayaan konsumen, semakin tinggi juga niat mereka untuk membeli. Oleh karena itu, kepercayaan sangat mempengaruhi keinginan konsumen untuk bertransaksi. Hasil penelitian Hajli (2013) menemukan bahwa kepercayaan berpengaruh positif dan signifikan pada niat beli konsumen. Hal serupa juga ditemukan oleh Nusarika dan Purnami (2015) yang memperoleh hasil bahwa semakin tinggi kepercayaan konsumen online akan menghasilkan niat beli konsumen yang lebih tinggi pula untuk berbelanja secara online. Berbeda dengan hasil penelitian yang dilakukan Smeait (2016) yang menemukan bahwa variabel kepercayaan atau keyakinan berpengaruh negatif terhadap minat beli produk fashion melalui online yang menandakan konsumen tidak yakin dengan melakukan pembelian secara langsung melalui online dengan tidak melihat produk yang akan di beli dengan harga yang sudah ditentukan oleh penjual.

Temuan penelitian Purwanto (2017) menyatakan bahwa semakin tinggi kepercayaan pembeli akan meningkatkan minat beli produk fashion. Hasil penelitian Rachmawati dkk. (2016) juga menemukan hasil bahwa variabel kepercayaan memiliki pengaruh positif dan signifikan terhadap minat beli pada transaksi jual beli online melalui media sosial. Semakin tinggi kepercayaan konsumen terhadap penjual produk secara online, maka semakin tinggi minat untuk membeli produk melalui media sosial. Dapat diasumsikan bahwa ketika responden menggunakan media sosial pada dasarnya mempercayai penjual yang menawarkan produk barang maupun jasa di media sosial. Oleh karena itu, semakin sering responden mengunjungi media sosial yang didalamnya ada seorang penjual yang menwarkan produk barang atau jasanya, kemungkinan tinggi bahwa mereka mempercayai penjual yang menjual produknya di media sosial tersebut. 
Berdasarkan hasil-hasil penelitian sebelumnya, maka dapat ditentukan hipotesis sebagai berikut:

$\mathrm{H}_{2}$ : Kepercayaan berpengaruh positif dan signifikan terhadap minat beli

Perceived usefulness memainkan peran penting dalam e-commerce dan memiliki dampak positif terhadap lingkungan sosial perdagangan. Hasil penelitian mengenai berbelanja di SNS menunjukkan bahwa semakin banyak konsumen yang berbelanja di SNS karena kegunaannya, semakin tinggi juga niat konsumen lainnya untuk berbelanja di SNS (Hajli, 2013).

Persepsi manfaat yang dirasakan terhadap suatu e-commerce dapat ditingkatkan ketika website e-commerce tersebut mampu memberikan manfaat atau memudahkan berlangsungnya suatu aktivitas belanja online dari penggunanya. Jika situs e-commerce dilengkapi dengan akses yang cepat, kemudahan pencarian produk, dan sesuai dengan kebutuhan pengguna maka hal tersebut dapat memunculkan sikap positif dari pengguna terhadap situs tersebut, sehingga dapat meningkatkan minat beli konsumen (Faradila dan Soesanto, 2016). Penelitian serupa oleh Lukas (2017) memperoleh hasil bahwa manfaat yang dirasakan konsumen (perceived usefulness) memiliki efek positif terhadap niat pembelian konsumen. Berbeda dengan hasil temuan Yudiarti (2017) dan Pratiwi (2018) yang menemukan bahwa perceived usefulness tidak berpengaruh signifikan terhadap minat membeli konsumen. Namun penelitian yang dilakukan oleh Basyar dan Sanaji (2016), Nursiah (2017) dan Jannah (2017) memperoleh hasil bahwa persepsi manfaat (perceived usefulness) berpengaruh positif dan signifikan pada minat beli konsumen. Hal ini menunjukkan bahwa persepsi kemanfaatan yang tinggi cenderung akan mendukung perubahan yang terjadi di dalam keputusan pembelian konsumen

Berdasarkan hasil-hasil penelitian sebelumnya, maka dapat ditentukan hipotesis sebagai berikut:

$\mathrm{H}_{3}$ : $\quad$ Perceived usefulness berpengaruh positif dan signifikan terhadap minat beli

Perceived usefulness dan kepercayaan merupakan faktor penting bagi konsumen untuk memutuskan akan melakukan transaksi secara online atau tidak. Temuan penelitian Purwanto (2017) menyatakan bahwa semakin tinggi kepercayaan pembeli akan meningkatkan minat beli produk fashion. Hasil penelitian Rachmawati dkk. (2016) juga menemukan hasil bahwa variabel kepercayaan memiliki pengaruh positif dan signifikan terhadap minat beli pada transaksi jual beli online melalui media sosial. Semakin tinggi kepercayaan konsumen terhadap penjual produk secara online, maka semakin tinggi minat untuk membeli produk melalui media sosial.

Selanjutnya penelitian oleh Lukas (2017) memperoleh hasil bahwa manfaat yang dirasakan konsumen (perceived usefulness) memiliki efek positif terhadap niat pembelian konsumen. Berbeda dengan hasil temuan Yudiarti (2017) dan Pratiwi (2018) yang menemukan bahwa perceived usefulness tidak berpengaruh signifikan terhadap minat membeli konsumen. Namun penelitian yang dilakukan oleh Basyar dan Sanaji (2016), Nursiah (2017) dan Jannah (2017) memperoleh hasil bahwa persepsi manfaat (perceived usefulness) berpengaruh positif dan signifikan pada minat beli konsumen. Hal ini menunjukkan bahwa persepsi 
kemanfaatan yang tinggi cenderung akan mendukung perubahan yang terjadi di dalam keputusan pembelian konsumen. Dengan demikian dapat disimpulkan bahwa konsumen yang sudah memiliki kepercayaan pada suatu situs belanja online, kemudian didukung dengan adanya persepsi manfaat yang baik bagi konsumen, maka dapat meningkatnya minat beli konsumen pada situs online tersebut.

Berdasarkan hasil-hasil penelitian sebelumnya, maka dapat ditentukan hipotesis sebagai berikut:

$\mathrm{H}_{4}$ : Perceived usefulness memediasi pengaruh kepercayaan terhadap minat beli

\section{METODE PENELITIAN}

Penelitian ini dilakukan di Kota Denpasar. Alasan Kota Denpasar dijadikan lokasi penelitian karena Kota Denpasar merupakan salah satu Kota yang memiliki kepadatan penduduk tertinggi di Bali dan di dukung dengan daya beli yang cukup tinggi, dimana mayoritas masyarakatnya merupakan masyarakat modern yang saat ini kebanyakan memenuhi kebutuhan hidupnya dengan menggunakan media online.

Tabel 2.

Variabel dan Indikator Penelitian

\begin{tabular}{|c|c|c|c|}
\hline No & Variabel & Indikator & Sumber \\
\hline 1. & $\begin{array}{c}\text { Kepercayaan } \\
\text { (X) }\end{array}$ & $\begin{array}{l}\text { 1. Dapat dipercaya }\left(\mathrm{X}_{1}\right) \\
\text { 2. Menepati janji }\left(\mathrm{X}_{2}\right) \\
\text { 3. Memberi informasi yang benar }\left(\mathrm{X}_{3}\right) \\
\text { 4. Mempermudah calon pembeli }\left(\mathrm{X}_{4}\right) \\
\text { 5. Cepat tanggap }\left(\mathrm{X}_{5}\right)\end{array}$ & $\begin{array}{l}\text { Rachmawati } \\
\text { dkk. (2016) }\end{array}$ \\
\hline 2. & $\begin{array}{l}\text { Perceived } \\
\text { usefulness } \\
\text { (M) }\end{array}$ & $\begin{array}{l}\text { 1. Memudahkan berbelanja secara cepat }\left(\mathrm{M}_{1}\right) \\
\text { 2. Membuat keputusan pembelian yang lebih baik } \\
\left(\mathrm{M}_{2}\right) \text {, } \\
\text { 3. Internet sebagai belanja yang lebih berguna } \\
\left(\mathrm{M}_{3}\right) \text {, } \\
\text { 4. Belanja internet menghemat waktu }\left(\mathrm{M}_{4}\right) \text {, } \\
\text { 5. Internet lebih mudah untuk melakukan } \\
\text { pembelian }\left(\mathrm{M}_{5}\right) \text {, }\end{array}$ & $\begin{array}{l}\text { Basyar dan } \\
\text { Sanaji (2016) }\end{array}$ \\
\hline 3. & $\begin{array}{l}\text { Minat Beli } \\
\text { (Y) }\end{array}$ & $\begin{array}{l}\text { 1. Berusaha mencari informasi }\left(\mathrm{Y}_{1}\right) \\
\text { 2. Senang menggunakan media sosial }\left(\mathrm{Y}_{2}\right) \\
\text { 3. Mempertimbangkan membeli produk }\left(\mathrm{Y}_{3}\right) \\
\text { 4. Berniat membeli produk }\left(\mathrm{Y}_{4}\right)\end{array}$ & $\begin{array}{l}\text { Rachmawati } \\
\text { dkk. (2016) }\end{array}$ \\
\hline
\end{tabular}

Sumber: Data diolah, 2018

Populasi dalam penelitian ini adalah konsumen di Kota Denpasar yang memiliki minat pembelian produk fashion pada toko online Zalora yang tidak diketahui jumlahnya secara pasti. Teknik non probability sampling yang dipilih adalah purposive sampling yaitu teknik penentuan sampel dengan pertimbangan tertentu. . Ukuran sampel dalam penelitian multivariat sebaiknya 5 - 10 kali lebih besar dibandingkan jumlah indikator variabel dalam studi. Penelitian ini menggunakan 14 indikator, sehingga dengan menggunakan estimasi berdasarkan 
jumlah parameter diperoleh ukuran sampel sebesar $70-140$ responden. Jumlah sampel yang digunakan dalam penelitian ini adalah sebanyak 110 responden.

Penelitian ini memakai teknik analisis jalur atau biasa disebut path analysis. Persamaan regresinya yaitu:

Persamaan Sub-struktural 1

$$
\mathrm{M}=\beta_{1} \mathrm{X}+\mathrm{e}_{1}
$$

Persamaan Sub-struktural 2

$$
\mathrm{Y}=\beta_{2} \mathrm{X}+\beta_{3} \mathrm{M}+\mathrm{e}_{2}
$$

Keterangan :

$$
\begin{aligned}
& \mathrm{X}=\text { kepercayaan } \\
& \mathrm{M}=\text { perceived usefulness } \\
& \mathrm{Y}=\text { minat beli } \\
& \beta_{1,}, \beta_{2}, \beta_{3}=\text { koefisien regresi variabel } \\
& \mathrm{e} \quad=\text { error }
\end{aligned}
$$

\section{HASIL DAN PEMBAHASAN}

Perhitungan koefisien path atau analisis jalur dilakukan dengan analisis regresi melalui software SPSS 18.0 for Windows, diperoleh hasil yang ditunjukan pada Tabel 3. berikut:

Tabel 3.

Hasil Analisis Jalur 1

\begin{tabular}{lcccc}
\hline \multicolumn{1}{c}{ Variabel } & Standardized Coefficients & Std. Error & t hitung & Sig. uji t \\
\hline (Constant) & 10,201 & 1,714 & 5,950 & 0,000 \\
Kepercayaan (X) & 0,473 & 0,086 & 5,580 & 0,000 \\
R Square & 0,224 & & & \\
F Statistik & 31,139 & & & \\
Signifikansi Uji F & 0,000 & & & \\
\hline
\end{tabular}

Sumber: Data diolah, 2018

Berdasarkan hasil analisis jalur substruktur 1 seperti yang disajikan pada Tabel 3, maka dapat dibuat persamaan struktural sebagai berikut:

$$
\mathrm{M}=0,473 \mathrm{X}+\mathrm{e}_{1}
$$

Nilai koefisien regresi variabel kepercayaan bernilai positif dengan nilai signifikansi uji t kurang dari 0,05 . Hal ini menunjukkan bahwa variabel kepercayaan memiliki pengaruh positif yang signifikan terhadap variabel perceived usefulness. Besarnya pengaruh variabel bebas terhadap variabel terikat yang ditunjukkan oleh nilai determinasi total ( $\mathrm{R}$ Square) sebesar 0,224 mempunyai arti bahwa sebesar 22,4\% variasi perceived usefulness dipengaruhi oleh variasi kepercayaan, sedangkan sisanya sebesar $77,6 \%$ dijelaskan oleh faktor lain yang tidak dimasukkan ke dalam model.

Pengujian ini menggunakan analisis regres linier berganda dengan analisis jalur. Hasil uji analisis dalam penelitian ini dapat disajikan pada tabel 4 di bawah ini: 
Tabel 4.

Hasil Analisis Jalur 2

\begin{tabular}{lcccc}
\hline \multicolumn{1}{c}{ Variabel } & $\begin{array}{c}\text { Standardized } \\
\text { Coefficients }\end{array}$ & Std. Error & t hitung & Sig. uji t \\
\hline (Constant) & 4,830 & 1,483 & 3,258 & 0,002 \\
Kepercayaan (X) & 0,262 & 0,073 & 2,937 & 0,004 \\
Perceived usefulness (M) & 0,412 & 0,072 & 4,626 & 0,000 \\
R Square & 0,341 & & & \\
F Statistik & 27,624 & & & \\
Signifikansi Uji F & 0,000 & & &
\end{tabular}

Sumber : Data diolah, 2018

Berdasarkan hasil analisis jalur substruktur 2 seperti yang disajikan pada Tabel 4. maka dapat dibuat persamaan struktural sebagai berikut :

$$
\mathrm{Y}=0,262 \mathrm{X}+0,412 \mathrm{M}+\mathrm{e}_{2}
$$

Nilai koefisien regresi masing-masing variabel bebas bernilai positif dengan nilai signifikansi uji t kurang dari 0,050. Hal ini menunjukkan bahwa semua variabel bebas memiliki pengaruh positif yang signifikan terhadap variabel terikat. Besarnya pengaruh variabel bebas terhadap variabel terikat yang ditunjukkan oleh nilai determinasi total ( $\mathrm{R}$ Square) sebesar 0,341 mempunyai arti bahwa sebesar $34,1 \%$ variasi minat beli dipengaruhi oleh variasi kepercayaan dan perceived usefulness, sedangkan sisanya sebesar $65,9 \%$ dijelaskan oleh faktor lain yang tidak dimasukkan ke dalam model.

Berdasarkan model substruktur 1 dan substruktur 2, maka dapat disusun model diagram jalur akhir. Sebelum menyusun model diagram jalur akhir, terlebih dahulu dihitung nilai standar eror sebagai berikut :

$$
\begin{aligned}
& \mathrm{Pe}_{\mathrm{i}}=\sqrt{1-\mathrm{R}_{\mathrm{i}}{ }^{2} \ldots \ldots \ldots \ldots \ldots \ldots \ldots \ldots \ldots \ldots \ldots \ldots \ldots \ldots \ldots} \ldots \\
& \mathrm{Pe}_{1}=\sqrt{1-R_{1}{ }^{2}}=\sqrt{1-0,224}=0,881 \\
& \mathrm{Pe}_{2}=\sqrt{1-R_{2}{ }^{2}}=\sqrt{1-0,341}=0,812
\end{aligned}
$$

Berdasarkan perhitungan pengaruh error (Pei), didapatkan hasil pengaruh error $\left(\mathrm{Pe}_{1}\right)$ sebesar 0,881 dan pengaruh error $\left(\mathrm{Pe}_{2}\right)$ sebesar 0,812 . Hasil koefisien determinasi total adalah sebagai berikut :

$$
\begin{aligned}
\mathrm{R}^{2} \mathrm{~m} & =1-\left(\mathrm{Pe}_{1}\right)^{2}\left(\mathrm{Pe}_{2}\right)^{2} \ldots \ldots \ldots \\
& =1-(0,881)^{2}(0,812)^{2} \\
& =1-(0,776)(0,659) \\
& =1-0,511=0,489
\end{aligned}
$$

Nilai determinasi total sebesar 0,489 mempunyai arti bahwa sebesar 48,9\% variasi minat beli konsumen pada produk fashion toko online Zalora di Kota Denpasar dipengaruhi oleh variasi kepercayaan dan perceived usefulness, sedangkan sisanya sebesar $51,1 \%$ djelaskan oleh faktor lain yang tidak dimasukkan ke dalam model. berikut.

Perhitungan pengaruh antar variabel dirangkum dalam Tabel 5. sebagai 
Tabel 5.

Pengaruh Langsung dan Pengaruh Tidak Langsung serta Pengaruh Total Variabel Penelitian

\begin{tabular}{cccc}
\hline $\begin{array}{c}\text { Pengaruh } \\
\text { Variabel }\end{array}$ & $\begin{array}{c}\text { Pengaruh } \\
\text { Langsung }\end{array}$ & $\begin{array}{c}\text { Pengaruh Tidak Langsung Melalui } \\
\text { Perceived usefulness } \\
(\mathbf{M})(\boldsymbol{\beta} \mathbf{1} \mathbf{\beta} \boldsymbol{\beta 3})\end{array}$ & Pengaruh Total \\
\hline $\mathrm{X} \rightarrow \mathrm{M}$ & 0,473 & - & 0,473 \\
$\mathrm{X} \rightarrow \mathrm{Y}$ & 0,262 & 0,195 & 0,457 \\
$\mathrm{M} \rightarrow \mathrm{Y}$ & 0,412 & - & 0,412 \\
\hline Sumber : Data diolah, 2018 & &
\end{tabular}

Untuk menguji signifikansi pengaruh tidak langsung maka nilai $\mathrm{z}$ dari koefisien ab dihitung dengan rumus sebagai berikut:

$$
\begin{aligned}
& S_{a b}=\sqrt{(0,334)^{2}(0,086)^{2}+(0,481)^{2}(0,072)^{2}+(0,086)^{2}(0,072)^{2}} \\
& S_{a b}=0,045418
\end{aligned}
$$

Keterangan :

$\mathrm{Sab}=$ besarnya standar error tidak langsung

$\mathrm{Sa} \quad=$ standar error koefisien $\mathrm{b} 1$

$\mathrm{Sb} \quad=$ standar error koefisien b3

a $\quad$ jalur X terhadap $\mathrm{M}$

$\mathrm{b} \quad=$ jalur $\mathrm{M}$ terhadap $\mathrm{Y}$

$\mathrm{ab} \quad=$ jalur $\mathrm{X}$ terhadap $\mathrm{M}$ (a) dengan jalur M terhadap $\mathrm{Y}(\mathrm{b})$

Untuk menguji signifikansi pengaruh tidak langsung maka menghitung nilai $\mathrm{z}$ dari koefisien $\mathrm{ab}$ dengan rumus sebagai berikut :

$$
\begin{aligned}
& Z=\frac{a b}{S a b} \ldots \ldots \ldots \ldots \ldots \ldots \ldots \ldots \ldots \ldots \ldots \ldots \ldots \ldots \\
& Z=\frac{(0,481)(0,334)}{0,045418} \\
& Z=3,5372 \text { dengan signifikansi } 0,000
\end{aligned}
$$

Oleh karena $\mathrm{Z}$ hitung sebesar 3,3572 > 1,96. Artinya Perceived usefulness (M) merupakan variabel yang memediasi kepercayaan (X) terhadap minat beli (Y) konsumen pada produk fashion toko online Zalora di Kota Denpasar atau dengan kata lain kepercayaan berpengaruh secara tidak langsung terhadap minat beli melalui perceived usefulness.

Hasil analisis menunjukkan bahwa kepercayaan berpengaruh positif dan signifikan terhadap perceived usefulness. Hal ini memiliki makna bahwa semakin tinggi kepercayaan konsumen pada produk fashion toko online Zalora, maka semakin tinggi pula persepsi manfaat yang dirasakan konsumen tersebut. Begitu pula sebaliknya, semakin rendah kepercayaan konsumen pada produk fashion toko online Zalora, maka semakin rendah pula persepsi manfaat yang dirasakan konsumen tersebut. 
Penelitian ini sesuai dengan hasil penelitian Sugiantoro dan Isharijadi (2015) yang memperoleh hasil bahwa variabel kepercayaan berpengaruh positif dan signifikan pada perceived usefulness. Sehingga upaya tinggi harus dilakukan oleh penyelenggara online shop agar kepercayaan konsumen semakin tinggi, karena kepercayaan mempunyai pengaruh besar pada pemanfaatan konsumen untuk melakukan transaksi secara online atau tidak melakukannya. Hasil penelitian ini juga mendukung penelitian yang dilakukan oleh Hajli (2013), Kusumawati (2015), Faradila dan Soesanto (2016), serta Purnami (2016) yang menyatakan bahwa terdapat pengaruh yang sigmifikan antara kepercayaan dengan persepsi manfaat. Apabila konsumen sudah merasa bahwa bertransaksi online mudah, bermanfaat dan menguntungkan, maka konsumen akan merasa semakin percaya dan puas terhadap layanan yang diberikan dan akan semakin loyal dengan layanan tersebut.

Konsumen yang memiliki kepercayaan yang tinggi akan memiliki perilaku minat beli yang lebih tinggi, dibandingkan dengan konsumen yang memiliki kepercayaan rendah. Kepercayaan dalam transaksi dan jaringan online mempengaruhi perilaku pembeli online dan meningkatkan niat untuk membeli. Interaksi antara pengguna online dalam SNS meningkatkan kepercayaan dan kepercayaan memiliki peran penting dalam mempengaruhi niat konsumen untuk membeli. Faktanya, semakin tinggi kepercayaan konsumen, semakin tinggi juga niat mereka untuk membeli. Oleh karena itu, kepercayaan sangat mempengaruhi keinginan konsumen untuk bertransaksi. Hasil analisis menunjukkan bahwa kepercayaan berpengaruh positif dan signifikan terhadap minat beli. Hal ini memiliki makna bahwa semakin tinggi kepercayaan yang dimiliki konsumen pada produk fashion toko online Zalora, maka minat beli konsumen akan semakin meningkat.

Penelitian ini sesuai dengan penelitian Nusarika dan Purnami (2015) yang memperoleh hasil bahwa semakin tinggi kepercayaan konsumen online akan menghasilkan niat beli konsumen yang lebih tinggi pula untuk berbelanja secara online. Hasil penelitian ini juga mendukung temuan Hajli (2013), Smeait (2016) Rachmawati dkk. (2016), dan Purwanto (2017) yang menemukan hasil bahwa variabel kepercayaan memiliki pengaruh positif dan signifikan terhadap minat beli pada transaksi jual beli online melalui media sosial. Semakin tinggi kepercayaan konsumen terhadap penjual produk secara online, maka semakin tinggi minat untuk membeli produk melalui media sosial. Dapat diasumsikan bahwa ketika responden menggunakan media sosial pada dasarnya mempercayai penjual yang menawarkan produk barang maupun jasa di media sosial. Oleh karena itu, semakin sering responden mengunjungi media sosial yang didalamnya ada seorang penjual yang menwarkan produk barang atau jasanya, kemungkinan tinggi bahwa mereka mempercayai penjual yang menjual produknya di media sosial tersebut.

Perceived usefulness memainkan peran penting dalam e-commerce dan memiliki dampak positif terhadap lingkungan sosial perdagangan. Persepsi manfaat yang dirasakan terhadap suatu e-commerce dapat ditingkatkan ketika website e-commerce tersebut mampu memberikan manfaat atau memudahkan berlangsungnya suatu aktivitas belanja online dari penggunanya. Jika situs $e$ - 
commerce dilengkapi dengan akses yang cepat, kemudahan pencarian produk, dan sesuai dengan kebutuhan pengguna maka hal tersebut dapat memunculkan sikap positif dari pengguna terhadap situs tersebut, sehingga dapat meningkatkan minat beli konsumen (Faradila dan Soesanto, 2016). Hasil analisis dalam penelitian ini menunjukkan bahwa perceived usefulness berpengaruh positif dan signifikan terhadap minat beli. Hal ini memiliki makna bahwa semakin baik persepsi manfaat yang dirasakan konsumen saat melakukan transaksi pada toko online Zalora, maka kecenderungan minat konsumen untuk melakukan pembelian juga semakin besar. Begitu pula sebaliknya, semakin buruk persepsi manfaat yang dirasakan konsumen saat melakukan transaksi pada toko online Zalora, maka kecenderungan minat konsumen untuk melakukan pembelian akan semakin berkurang.

Penelitian ini sesuai dengan hasil penelitian Lukas (2017) yang memperoleh hasil bahwa manfaat yang dirasakan konsumen (perceived usefulness) memiliki efek positif terhadap niat pembelian konsumen. Penelitian ini juga mendukung beberapa hasil penelitian sebelumnya oleh Basyar dan Sanaji (2016), Nursiah (2017) dan Jannah (2017) memperoleh hasil bahwa persepsi manfaat (perceived usefulness) berpengaruh positif dan signifikan pada minat beli konsumen. Hal ini menunjukkan bahwa persepsi kemanfaatan yang tinggi cenderung akan mendukung perubahan yang terjadi di dalam keputusan pembelian konsumen.

Perceived usefulness dan kepercayaan merupakan faktor penting bagi konsumen untuk memutuskan akan melakukan transaksi secara online atau tidak. Apabila Zalora mampu membentuk kepercayaan yang tinggi bagi konsumen, maka kepercayaan tersebut akan mampu meningkatkan perceived usefulness konsumen dan pada akhirnya minat beli konsumen pada produk fashion toko online Zalora akan semakin meningkat. Berdasarkan hasil uji Sobel, ditemukan pengaruh yang positif antara variabel kepercayaan terhadap minat beli melalui variabel perceived usefulness. Hasil penelitian ini konsisten dengan temuan Rachmawati dkk. (2016) dan Purwanto (2017) yang menemukan hasil bahwa variabel kepercayaan memiliki pengaruh positif dan signifikan terhadap minat beli pada transaksi jual beli online melalui media sosial. Semakin tinggi kepercayaan konsumen terhadap penjual produk secara online, maka semakin tinggi minat untuk membeli produk melalui media sosial.

Konsumen yang sudah memiliki kepercayaan yang tinggi pada produk Zalora, tentu sudah mengetahui kualitas produk tersebut sehingga akan dapat mendorong timbulnya persepsi manfaat yang tinggi bagi konsumen, dan pada akhirnya akan mampu meningkatkan minat beli konsumen pada produk fashion toko online Zalora. Maka dapat disimpulkan bahwa perceived usefulness dapat memediasi kepercayaan terhadap minat beli konsumen. Penelitian juga mendukung hasil penelitian Basyar dan Sanaji (2016), Lukas (2017), Nursiah (2017) dan Jannah (2017) yang memperoleh hasil bahwa persepsi manfaat (perceived usefulness) berpengaruh positif dan signifikan pada minat beli konsumen. Hal ini menunjukkan bahwa persepsi kemanfaatan yang tinggi cenderung akan mendukung perubahan yang terjadi di dalam keputusan pembelian konsumen. Dengan demikian dapat disimpulkan bahwa konsumen yang sudah 
memiliki kepercayaan pada suatu situs belanja online, kemudian didukung dengan adanya persepsi manfaat yang baik bagi konsumen, maka dapat meningkatnya minat beli konsumen tersebut.

\section{SIMPULAN}

Kepercayaan berpengaruh positif dan signfikan terhadap perceived usefulness. Hal ini memiliki makna bahwa semakin percaya masyarakat Kota Denpasar pada produk fashion toko online Zalora, maka dapat membentuk persepsi manfaat yang semakin tinggi. Kepercayaan berpengaruh positif dan signfikan terhadap minat beli konsumen. Hal ini memiliki makna bahwa semakin percaya masyarakat Kota Denpasar pada produk fashion toko online Zalora, maka dapat membentuk minat beli yang semakin meningkat.

Perceived usefulness berpengaruh positif dan signifikan terhadap minat beli konsumen. Hal ini memiliki makna bahwa semakin baik persepsi manfaat yang dirasakan masyarakat Kota Denpasar saat melakukan transaksi pada toko online Zalora, maka minat untuk melakukan pembelian juga semakin besar. Perceived usefulness secara positif dan signifikan memediasi pengaruh kepercayaan terhadap minat beli konsumen. Hal ini memiliki makna bahwa kepercayaan yang sudah terbentuk pada produk fashion toko online Zalora, kemudian didukung dengan adanya persepsi manfaat yang baik bagi konsumen, maka dapat membentuk minat beli pada situs online Zalora yang semakin meningkat.

Pihak manajemen Zalora sebaiknya mempertimbangan dan mengevaluasi mengenai minat beli konsumen serta faktor-faktor yang memengaruhinya dengan cara meningkatkan kualitas costumer service agar mampu melayani dan menanggapi keluhan konsumennya dengan cepat tanggap. Kemudian dalam upaya meningkatkan perceived usefulness pada masyarakat Kota Denpasar, maka sebaiknya Zalora selalu melakukan update aplikasi yang dapat mempermudah pelanggan dalam membuat keputusan pembelian yang lebih baik. Selanjutnya, dalam upaya meningkatkan minat beli konsumen pada produk fashion toko online Zalora, maka pihak manajemen Zalora sebaiknya menambah koleksi produk fashion lokal dan menawarkan harga yang bersaing, agar dapat membentuk minat beli yang tinggi pada produk fashion toko online Zalora.

Hasil penelitian ini diharapkan mampu mendorong peneliti-peneliti selanjutnya untuk mengamati faktor-faktor lain yang dapat mempengaruhi minat beli konsumen selain kepercayaan dan perceived usefulness. Penelitian selanjutnya juga disarankan untuk dapat menambah jumlah sampel penelitian, serta memperluas wilayah penelitian, sehingga hasilnya dapat digeneralisasikan untuk lingkup yang lebih luas.

\section{REFERENSI}

Basyar, K. (2016). Pengaruh Persepsi Kemudahan Dan Persepsi Manfaat Terhadap Niat Beli Ulang Secara Online Dengan Kepuasaan Sebagai Variabel Intervening. Jurnal Bisnis Dan Manajemen, 8(2).

Ba, S., and Pavlou, P.A. 2002. Evidence of the Effect of Trust Building Technology in Electronic Markets: Price Premium and Buyer Behavior. MIS Quarterly, 26(3), pp. 243-268 
Badan Pusat Statistik. 2017. Provinsi Bali Dalam Angka 2017. Denpasar: BPS Bali

Faradila, R.S.N. dan H. Soesanto. 2016. Analisis Pengaruh Persepsi Kemudahan Penggunaan dan Persepsi Manfaat terhadap Minat Beli dengan Kepercayaan Sebagai Variabel Intervening (Studi pada Pengunjung Toko Online berrybenka.com di Kalangan Mahasiswa Universitas Diponegoro). Jurnal Studi Manajemen \& Organisasi. Vol. 13 Hal: 149 - 160

Hajli., M.N. 2013. A study of the impact of social media on consumers. International Journal of Market Reasearch. 56(3), 387-404

Ika, N. dan Kustini. 2011. Experiental Marketing, Emotional Branding, and Brand Trust and their Effect on Loyalty on Honda Motorcycle Product. Journal of Economics, Business, and Accountancy Ventura, 14 (1), pp: 19- 28.

Jannah, N.Z. 2017. Pengaruh Perceived Ease of Use dan Perceived usefulness Terhadap Buying Interest dan Buying Decision Melalui Aplikasi Go-Jek di Kota Samarinda. eJournal Administrasi Bisnis, 5 (4). Hal: 1014-1028

Juniwati. 2015. Pengaruh Perceived Ease of Use, Enjoyment dan Trust Terhadap Repurchase Intention dengan Customer Satisfaction Sebagai Intervening pada Belanja Online (Studi Pada Mahasiswa Universitas Tanjungpura Pontianak). Jurnal Ekonomi Bisnis dan Kewirausahaan, Vol. 4, No. 1, Hal: 140-156

Kusumawati, E. 2015. Pengaruh Persepsi Risiko, Persepsi Manfaat, Dan Persepsi Kemudahan Penggunaan Internet Banking Terhadap Kepercayaan Nasabah Dalam Menggunakan Layanan Internet Banking di BRI KCP Tanjung Agung. E-Journal Universitas Lampung. Hal:1-72

Li, Na and Zhang, Ping. 2002. Consumer Online Shopping Attitudes and Behavior: an Assessment of Research. Eighth Americas Conference on Information Systems. pp. 508-517

Liang, T. and Turban, E. (2011) Introduction to the Special Issue Social Commerce: A Research Framework for Social Commerce. International Journal of Electronic Commerce, 16, 5-14.

Lukas, P. 2017. Pengaruh Perceived Risk, Trust, Perceived usefulness, Dan Perceived Ease Of Use Terhadap Purchase Intention Pada Website Lazada. Artikel Ilmiah. Fakultas Bisnis Universitas Katolik Widya Mandala. Hal:119

Mubarak, S.A., dan B. Sanawiri. 2018. Pengaruh Fashion Lifestyle Terhadap Purchase Intention (Studi Pada Konsumen Pakaian Second Hand @ Tangankedua). Jurnal Administrasi Bisnis (JAB). Vol. 55 No. 3, Hal:3340 
Nursiah, N. 2017. Pengaruh Perceived Ease Of Use Dan Perceived usefulness Terhadap Behavior Intention To Use. Jurnal Elektronik Sistem Informasi dan Komputer. Vol3. No.2, Hal: 39-47

Nusarika, L.A.K., dan N.M. Purnami. 2015. Pengaruh Persepsi Harga, Kepercayaan, Dan Orientasi Belanja Terhadap Niat Beli Secara Online (Studi pada Produk Fashion Online di Kota Denpasar). E-Jurnal Manajemen Unud, Vol. 4, No. 8, Hal: 2380-2406

Pratiwi, M.J. 2016. Analisis Pengaruh Trust, Perceived Ease Of Use, Perceived usefulness, Risk Dan Kualitas Informasi Terhadap Minat Bertransaksi Menggunakan Sistem E Commerce (Studi Empiris Mengenai Persepsi Pada Mahasiswa Akuntansi Fakultas Ekonomi dan Bisnis Universitas Muhammadiyah Surakarta). Publikasi Ilmiah. Fakultas Ekonomi dan Bisnis Universitas Muhammadiyah Surakarta. Hal: 1-15

Purnami, R. 2016. Pengaruh Persepsi Manfaat, Persepsi Keamanan Dan Kerahasiaan, Kepuasan Nasabah Terhadap Kepercayaan Nasabah Pada Layanan E-Banking Bank Mandiri Di Surabaya. Artikel Ilmiah. Sekolah Tinggi Ilmu Ekonomi Perbanas. Hal: 1-15

Purwanto, S. 2017. Perilaku Pembelian Produk Fashion Didasarkan Pada Kepercayaan Menggunakan Media Sosial. Ekspektra, Jurnal Manajemen dan Bisnis. 1(1): 55-67

Setiawati, M. 2015. Pengaruh Media Sosial Terhadap Minat Beli Konsumen Studi Kasus Mahasiswa Manajemen Universitas Pasir Pengaraian. Artikel Ilmiah. Fakultas Ekonomi Universitas Pasir Pengaraian. Hal:1-13

Smeait, A. 2016. Faktor-Faktor Yang Mempengaruhi Minat Beli Pada Produk Fashion Melalui Belanja Online. Jurnal Publikasi Fakultas Ekonomi Manajemen Universitas Muhammadiyah Yogyakarta. Hal:1-13

Statistic dan Data Portal Databoks.co.id. 2016. Produk Fashion Paling Banyak Diburu Konsumen Online. https://databoks.katadata.co.id/datapublish/2016/ 12/22/produk-fashion-paling-banyak-diburu-konsumen-online.Diakses pada tanggal 2 Agustus 2018

Statistic dan Data Portal Databoks.co.id. 2018. Lazada, e-commerce Paling Banyak Pengunjung TW I 2018. https://databoks.katadata.co.id/ datapublish/2018/04/18/lazada-e-commerce-paling-banyak-pengunjung-twi-2018. Diakses pada tanggal 2 Agustus 2018

Sugiantoro, Y. dan Isharijadi. 2015. Pengaruh Personalization, Computer Self Efficacy, Dan Trust Terhadap Perceived Usefullness Pada Pengguna Internet Banking Di Pt. Bank BRI (Persero), Tbk. Cabang Madiun. Jurnal Akuntansi dan Pendidikan, Vol.4 No.1, Hal : 82-91 
Weisberg, J., Dov T., and Amar, L. 2011. Past Purchase and Intention to Purchase in e-commerce. The Mediation of Social Presence and Trust. Internet Research, 21(1):82-96.

Yudiarti, Rr. Fradiani Eka (2017) Peran Trust Sebagai Mediasi Pengaruh Perceived usefulness Dan Perceived Ease Of Use Terhadap Minat Beli EBook (Studi Pada Mahasiswa S2 Universitas Brawijaya Malang) ). Magister thesis, Universitas Brawijaya) 